\title{
Transient Cavitation and Friction-Induced Heating Effects of Diesel Fuel during the Needle Valve Early Opening Stages for Discharge Pressures up to $450 \mathrm{MPa}$
}

\author{
Konstantinos Kolovos ${ }^{1, *}$, Phoevos Koukouvinis ${ }^{1}$, Robert M. McDavid ${ }^{2}$ and Manolis Gavaises ${ }^{1, *}$ \\ 1 Department of Mechanical Engineering \& Aeronautics, School of Mathematics, Computer Sciences \& \\ Engineering, City University of London, London EC1V 0HB, UK; foivos.koukouvinis.1@city.ac.uk \\ 2 Caterpillar Inc., Mossville, IL 61552, USA; mcdavid_robert_m@cat.com \\ * Correspondence: konstantinos.kolovos.2@city.ac.uk (K.K.); m.gavaises@city.ac.uk (M.G.)
}

check for updates

Citation: Kolovos, K.; Koukouvinis, P.; McDavid, R.M.; Gavaises, M. Transient Cavitation and Friction-Induced Heating Effects of Diesel Fuel during the Needle Valve Early Opening Stages for Discharge Pressures up to $450 \mathrm{MPa}$. Energies 2021, 14, 2923. https://doi.org/ $10.3390 /$ en14102923

Academic Editor: Roberto Cipollone

Received: 29 March 2021

Accepted: 10 May 2021

Published: 18 May 2021

Publisher's Note: MDPI stays neutral with regard to jurisdictional claims in published maps and institutional affiliations.

Copyright: (c) 2021 by the authors. Licensee MDPI, Basel, Switzerland. This article is an open access article distributed under the terms and conditions of the Creative Commons Attribution (CC BY) license (https:/ / creativecommons.org/licenses/by/ $4.0 /)$.

\begin{abstract}
An investigation of the fuel heating, vapor formation, and cavitation erosion location patterns inside a five-hole common rail diesel fuel injector, occurring during the early opening period of the needle valve (from $2 \mu \mathrm{m}$ to $80 \mu \mathrm{m}$ ), discharging at pressures of up to $450 \mathrm{MPa}$, is presented. Numerical simulations were performed using the explicit density-based solver of the compressible Navier-Stokes (NS) and energy conservation equations. The flow solver was combined with tabulated property data for a four-component diesel fuel surrogate, derived from the perturbed chain statistical associating fluid theory (PC-SAFT) equation of state (EoS), which allowed for a significant amount of the fuel's physical and transport properties to be quantified. The Wall Adapting Local Eddy viscosity (WALE) Large Eddy Simulation (LES) model was used to resolve sub-grid scale turbulence, while a cell-based mesh deformation arbitrary Lagrangian-Eulerian (ALE) formulation was used for modelling the injector's needle valve movement. Friction-induced heating was found to increase significantly when decreasing the pressure. At the same time, the Joule-Thomson cooling effect was calculated for up to 25 degrees $\mathrm{K}$ for the local fuel temperature drop relative to the fuel's feed temperature. The extreme injection pressures induced fuel jet velocities in the order of $1100 \mathrm{~m} / \mathrm{s}$, affecting the formation of coherent vortical flow structures into the nozzle's sac volume.
\end{abstract}

Keywords: cavitation; real-fluid; $450 \mathrm{MPa}$ injection pressure; erosion; LES; ALE

\section{Introduction}

Although $\mathrm{CO}_{2}$ emissions during 2020 decreased because of the COVID-19 pandemic, other global greenhouse gas concentrations (methane $\left(\mathrm{CH}_{4}\right)$ and nitrous oxide $\left(\mathrm{N}_{2} \mathrm{O}\right)$ ) in the atmosphere continued to rise. Overall, this short-term reduction in $\mathrm{CO}_{2}$ emissions is expected to have a negligible long-term impact on climate change [1]. At the same time, the forecasted unprecedented scale of COVID-19 economic recovery measures must consider sustainable low-carbon technologies that require the implementation of longterm technology changes for achieving a reduction in emissions. The projected increases in heavy-duty global transportation-related energy demands through 2040 is driven by economic activity [2], which leads to increased commerce and movement of goods across oceans, nations, and cities. For example, a light commercial vehicle (LCV) for intra-city deliveries has different energy needs versus a heavy commercial vehicle (HCV) for crosscountry shipments of goods. Additionally, truck fleets are often quite different from region to region. Enhancements in technology and operations will improve the fuel efficiency and consumption in these diverse sectors, which are dependent on the type of truck and its use [2]. As electrification technologies and infrastructure continue to be developed, energy and transportation power system portfolios, consisting of a range of solutions including efficient engines with ultra-low emissions, will be required to mitigate the environmental consequences of fossil fuel utilization. High pressure fuel injection, in particular is one of the key technologies affecting engine efficiency and emissions. 
Diesel surrogates could lead to a decrease in soot formation during combustion in all types of internal combustion engines [3-8], while multiple injections significantly reduce both soot and NOx emissions [9]. The increasing consumption of biofuels may produce a major effect against global warming $[5,10,11]$. Experimental data have shown that increasing the injection pressure will cause a reduction in soot formation [12,13]. An extended experimental study, performed with up to $320 \mathrm{MPa}$, revealed that if the same mass is injected at higher injection pressures, the injection and combustion processes may be optimized significantly. The combustion times are significantly reduced by the increase in injection pressure, as the atomization and vaporization efficiency are improved [14]. A detailed experimental work analyzed the behavior of the evaporation, mixing, and combustion of a diesel spray at injection pressures of up to $500 \mathrm{MPa}$, revealing improved mixing due to higher spray velocities [15].

However, the $\mu \mathrm{m}$-scale of injectors makes experimental flow characterization inside the injector challenging, especially under such high injection pressures. Increasing the injection pressure results in very high fuel velocities combined with high fuel temperature, and sharp pressure and temperature gradients, leading to the formation of cavitation. Although cavitation collapse may remove surface deposits [16,17] and improve primary jet break-up [18-21], it may also damage the injector material [22,23] and reduce the injector mass flow rate performance [24-28].

A limited number of studies have addressed fuel heating/cooling and phase-change in high pressure diesel injectors. Early studies $[28,29]$ utilized URANS, and were performed under fixed needle valve conditions with up to $300 \mathrm{MPa}$ of injection pressure. In follow up work $[26,30]$, the transient effects resulting from the needle motion showed significant variations in temperature during the opening/closing phase, suggesting that simulations performed at a fixed needle lift cannot represent the actual phenomenon. Furthermore, these works utilized the fuel properties from [31] and did not consider the link between cavitation and induced erosion. Recently, new experiments on the properties of diesel fuel at elevated pressures and temperatures have been performed, allowing for the development and calibration of perturbed chain statistical associating fluid theory (PC-SAFT) EoS, as reported by the authors in [32-39]. Another study accurately predicted the thermal conductivity of fuels at high temperature and 450-MPa pressure conditions using entropy scaling [34]. Relevant to this study, the thermophysical properties, such as density and viscosity, were modelled using the PC-SAFT theory for pressures up to $450 \mathrm{MPa}$ [39]. Theoretical predictions were made for up to $400 \mathrm{MPa}$ pressures, resulting in satisfactory accuracy for the density, isothermal compressibility, and volumetric thermal expansion. Tabulated data were derived for various fuel surrogates covering the range of properties occurring within high pressure fuel injectors, and thus allowing for an accurate estimation of the effects of the various fuel properties to be considered. The recent publication [40] described a more accurate way to predict the effects of various properties of a realistic multicomponent diesel surrogate at different conditions using PC-SAFT. The aim of that work was to investigate the in-nozzle flow and cavitation formation in a heavy-duty diesel injector under fixed needle valve conditions at up to $450 \mathrm{MPa}$ injection pressure. Recent works [41-44] have investigated the effect of cavitation and fuel properties on nozzle flow, spray formation and induced erosion in fuel injectors using a two-fluid approximation in AVL Fire.

Concerning works considering the movement of wall boundaries, Koukouvinis et al. [45,46] implemented a layering algorithm, adding/removing a layer of cells in FLUENT Ansys [46]. The transient effects due to the needle movement have been also taken into account by Devassy et al. [47] and Batistoni and Grimaldi [48]. In the literature [49], the moving needle effects of a diesel injector on the development of the cavitating flow and spray flow characteristic parameters were investigated [50]. A significant contribution in the field of mesh motion in pistons and Gasoline Direct Injection (GDI) injectors has been also made in [51]; they implemented a parallel algorithm for layer addition-removal in OpenFOAM and performed LES studies. Wu et al. [52] expanded on the idea of a dynamic length-scale 
resolution model (DLRM), which includes an adaptive rescaling procedure for both turbulent length and time scales for a simplified square-piston engine. The latest state of the art study for moving-needle diesel injectors is [53]. In [54], the authors implemented Immersed Boundary Method (IBM) in OpenFOAM ${ }^{\circledR}$ coupled with a multiphase compressible solver suitable for cavitation. Örley et al. [53] employed a conservative cut-element-based IBM for modelling the needle motion, and took into account the vapor and gas phases and also incorporated the LES turbulence model. They employed a barotropic two-phase two-fluid model, where all phases are represented by the homogeneous equilibrium model (HEM). An overset method was used for resolving challenging problems like a bullet fling through the muzzle flow field [55]. Khaware et al. [56] validated the accuracy of the overset method for cavitating flow problems using a multi-phase RANS flow solver and HEM in [56]. Koci et al. [57] used the dynamic Cartesian cut-cell mesh moving method in the CONVERGE ${ }^{\circledR}$ v2.3 CFD package for simulating the fuel injector nozzle flow using the finite volume methodology combined with the VoF method for simulating the multiphase flow. An arbitrary Lagrangian-Eulerian (ALE) framework with geometric conservation laws was used by Guventurk et al. [58] for simulating a single rising bubble in a Newtonian fluid.

Still, the transient effects caused by the motion of a needle valve for up to $450 \mathrm{MPa}$ of injection pressure are not yet available in the literature. From the above review, it seems that there are no relevant simulations or experiments reported for cavitation and induced erosion while considering variable fuel properties due to temperature/pressure gradients, and incorporating the transient effects caused by the motion of the needle valve. The aim of the current work is to address these phenomena and to simulate the flow inside a highpressure diesel injector discharging at $180 \mathrm{MPa}, 350 \mathrm{MPa}$, and $450 \mathrm{MPa}$ of pressure. For this purpose, the explicit, density-based flow solver reported in [59] has been implemented in OpenFOAM and has been coupled with the tabulated fuel property data derived from PC-SAFT EoS, as documented in [34-41]. All of the phases are represented by the HEM approach; the cavitation model is based on a thermodynamic multiphase equilibrium assumption. The injector needle valve movement is represented by the ALE approach, as proposed in [60], guaranteeing the enforcement of the space conservation law (SCL). One of the important features of the developed model is the incorporation of the wall adaptive eddy (WALE) [61] LES model. Model predictions are also compared against the experimental data reported in [46] for a five-hole diesel injector.

This paper is structured as follows: first, the mathematical and physical model is presented. Then, the discretization and the thermodynamic closure are analyzed, followed by the description of the diesel injector geometry and the computational setup, followed by the analysis of the three-dimensional flow-field for the early opening injection phase; this includes an analysis of the viscous fuel heating and cooling due to depressurization. Next, the flow-field for the early opening injection phase is presented, while in the final section, the results from the computational analysis are compared with the erosion pattern retrieved from the experiments. Limitations such as (i) the lack of detailed validation against experimental data, (ii) the assumption of local mechanical and thermal equilibrium adopted and (iii) the assumption of adiabatic nozzle walls have been evaluated in detail in [40], and thus they are not repeated here.

\section{Materials and Methods}

\subsection{Mathematical and Physical Model}

The explicit density-based flow solver is based on the works of $[45,59,62]$. The mathematical model employs a set of conservation equations governing the fluid motion, recasted in the form of the space conservation law, suitable for moving/deforming meshes. The equations, with notations from [60] and written in weak (integral) form, are given below (bold denotes vector/tensor and italic denotes scalar variables):

- Continuity equation: 


$$
\frac{\partial}{\partial t} \int_{V} \rho d V+\int_{A}\left(\rho \boldsymbol{u}_{r}\right) \cdot \boldsymbol{n} d A=0
$$

Here, $\rho$ represents the fluid density, $\boldsymbol{u}_{r}$ is the relative velocity of the fluid with respect to the velocity of the moving grid, $u_{g}$ is defined as $\boldsymbol{u}_{r}=\boldsymbol{u}-\boldsymbol{u}_{g}, n$ is the surface normal to the local grid face, $V$ index is the volume integral, and $A$ is the surface integral.

- Momentum conservation equation:

$$
\frac{\partial}{\partial t} \int_{V} \rho \mathbf{u} d V+\int_{A}\left(\rho \mathbf{u} \otimes \mathbf{u}_{\mathrm{r}}\right) \cdot \mathbf{n} d A=-\int_{A} p \mathbf{n} d A+\int_{A} \boldsymbol{\tau} \cdot \mathbf{n} d A
$$

Here, $p$ denotes the fluid pressure and $\tau$ is the viscous stress tensor, defined as follows:

$$
\boldsymbol{\tau}=\mu_{e f f}\left[\nabla \boldsymbol{u}+(\nabla \boldsymbol{u})^{T}\right]-2 / 3 \mu \nabla \cdot \boldsymbol{u}
$$

where $\mu_{\text {eff }}$ is the effective viscosity of the fluid, including both the turbulent $\left(\mu_{t}\right)$ and laminar $(\mu)$ viscosities.

- Energy conservation equation:

$$
\frac{\partial}{\partial t} \int_{V} \rho E d V+\int_{A}\left(\mathbf{u}_{\mathbf{r}} \rho E\right) \cdot \mathbf{n} d A=-\int_{A} p \mathbf{u} \cdot \mathbf{n} d A+\int_{A}\left(k_{e f f} \nabla T\right) \cdot \mathbf{n} d A+\int_{A}(\boldsymbol{\tau} \cdot \nabla \mathbf{u}) \cdot \mathbf{n} d A
$$

where $E$ represents the total energy; $T$ is the temperature of the fluid; and $\boldsymbol{k}_{\text {eff }}$ is the effective thermal conductivity of the fluid, including both the turbulent $\left(k_{t}\right)$ and laminar $(k)$ thermal conductivity.

- $\quad$ The volume change of cells due to mesh motion can be expressed as:

$$
\frac{\partial}{\partial t} \int_{V} d V+\int_{A} \boldsymbol{u}_{r} \cdot \boldsymbol{n} d A=0
$$

For the system closure, expressions for pressure and temperature are necessary in order to complete Equations (2) and (4). These are obtained from the thermodynamic closure or from the Equation of State (EoS) employed, which enables defining the relations of $T=f(\rho, e)$ and $p=f(\rho, e)$.

\subsection{Thermodynamic Model: Thermodynamic Properties Derived from the PC-SAFT EoS}

Instead of solving the EoS for each time step, a technique similar to that described by the authors in [59] was employed. A structured thermodynamic table containing the thermodynamic properties of a multicomponent diesel fuel surrogate, as explained in [40], derived from PC-SAFT EoS [63], was utilized, as explained in [64].

\subsection{Description of the Examined Injector and Testing Conditions}

The simulated geometry is presented in Figure 1, while the specific dimensions of the injector featuring slightly tapered holes are given in Table 1 . The injector consisted of five orifices, but only $1 / 5$ th of the full injector was simulated, employing symmetry boundary conditions. The computational mesh used consisted of a hexahedral block-structured zone, while an unstructured tetrahedral zone was used in the sac volume upstream of the orifice entrance. The mesh motion was performed with a cell-based deformation algorithm, which moved the computational points and cells and stretched them uniformly. The needle lift was initially set at $2 \mu \mathrm{m}$, with five cells placed in the needle seat flow passage. The initial flow field was obtained from a steady-state simulation performed at the minimum lift. The computational mesh of the sac volume and injection hole, which did not change throughout the simulation, are shown in Figure $1 b, c$ respectively. 


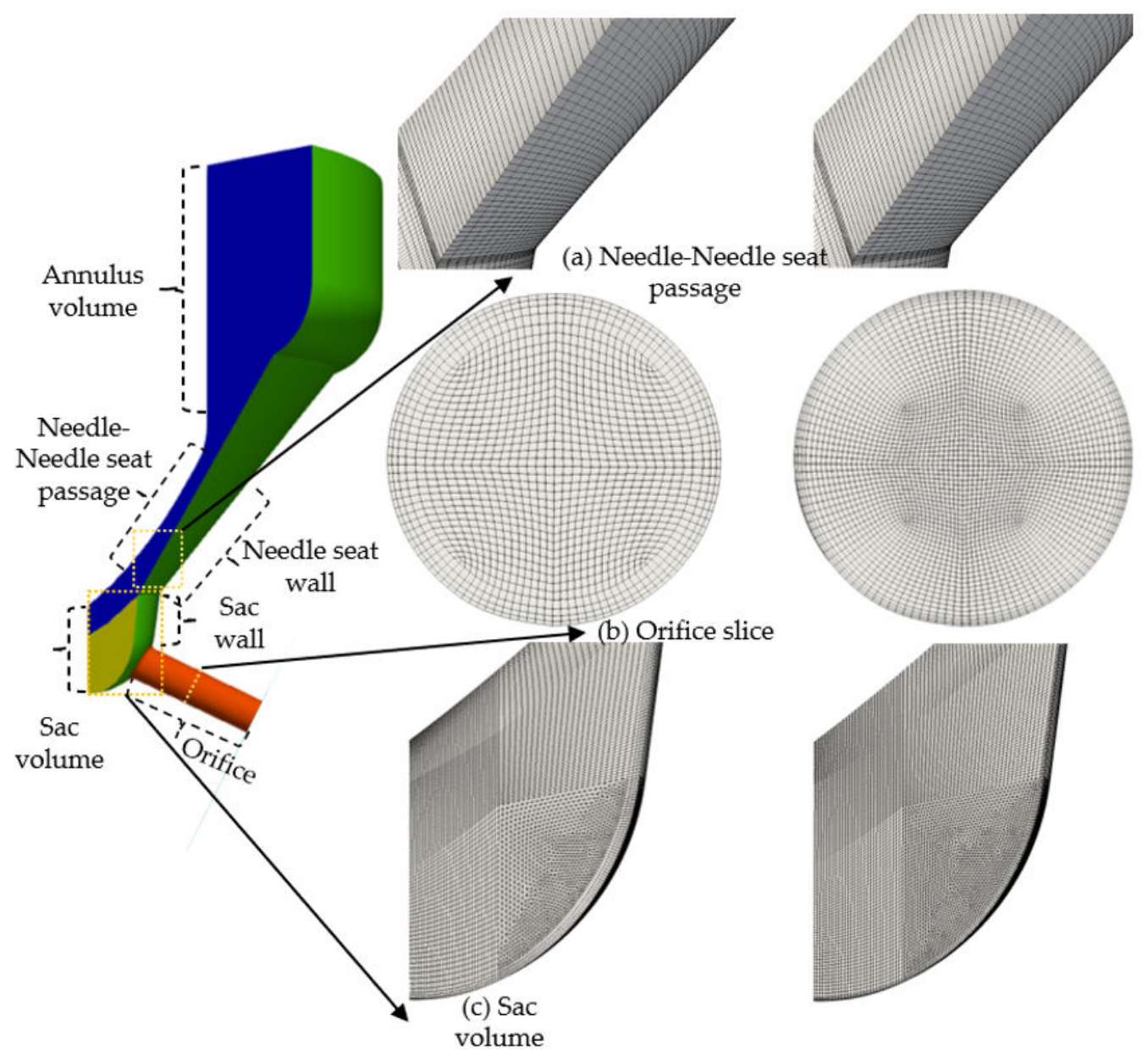

Figure 1. Naming convention of injector surfaces and 3D view of the computational domains at a $70 \mu \mathrm{m}$ needle lift, utilized for resolving the flow for the different injection pressures considered. The computational mesh of: (a) needle-needle seat passage, (b) injection hole and (c) sac volume; grids $(\mathbf{b}, \mathbf{c})$ do not change throughout the simulation.

Table 1. Geometric dimensions of the examined injector.

\begin{tabular}{ccc}
\hline & Unit & Value \\
\hline Max. Needle radius & $\mathrm{mm}$ & 1.711 \\
Orifice length & $\mathrm{mm}$ & 1.262 \\
Orifice diameter of the inlet & $\mathrm{mm}$ & 0.370 \\
Orifice diameter of the outlet & $\mathrm{mm}$ & 0.359 \\
Sac volume & $\mathrm{mm}^{3}$ & 1.190 \\
K-factor $\left(\mathrm{D}_{\text {in }}-\mathrm{D}_{\text {out }}\right) / 10$ & - & 1.1 \\
\hline
\end{tabular}

Figure 2 shows the inlet pressure and needle valve lift used as the boundary conditions in the CFD simulations. Both the $350 \mathrm{MPa}$ and $450 \mathrm{MPa}$ cases used the same needle lift. However, it is noted that this lift profile was optimized for the $350 \mathrm{MPa}$ case, as indicated using 1D hydraulic system performance analysis software. The needle motion was assumed to be in the z-axial direction only. No eccentricity or residual fuel effects were considered; such effects have been investigated in [65-69]. In Table 2, the numerical values for the reference state for the inlet and outlet, respectively, are provided. The simulations were carried out using the WALE model [70]. In [40] (Table 4), a mesh independency study showed the differences in the mass flow rate at the exit for the most refined mesh, decreasing the smallest cell sizes to $1.06 \mu \mathrm{m}$; therefore, the $1.5 \mathrm{M}$ cells mesh was used for all of the following simulations. 
Table 2. Boundary conditions at the inlet and outlet.

\begin{tabular}{ccccc}
\hline Property & Unit & $\mathbf{1 8 0} \mathbf{~ M P a}$ & $\mathbf{3 5 0} \mathbf{~ M P a}$ & $\mathbf{4 5 0} \mathbf{~ M P a}$ \\
\hline Inlet Temperature & {$[\mathrm{K}]$} & 350 & 350 & 350 \\
Inlet Density & {$\left[\mathrm{kg} / \mathrm{m}^{3}\right]$} & 885.5 & 948.7 & 979.8 \\
Outlet pressure & {$[\mathrm{MPa}]$} & 5 & 5 & 5 \\
\hline
\end{tabular}

The following values correspond to the Taylor length scales $\left(\lambda_{g}\right)$ :

$$
\lambda_{g}=\sqrt{10} R e^{-0.5} L
$$

As shown in Table 3, the injector geometry was divided into three topologies with different characteristics. The Reynolds numbers for the injector did not vary significantly between the needle seat, sac, and orifice volume.

Table 3. Numerically estimated Reynolds numbers.

\begin{tabular}{cccc}
\hline Test Case & $\begin{array}{c}\text { Reynolds Number } \\
\text { Needle Seat }\end{array}$ & $\begin{array}{c}\text { Reynolds Number } \\
\text { Sac Volume }\end{array}$ & $\begin{array}{c}\text { Reynolds Number } \\
\text { Orifice Volume }\end{array}$ \\
\hline $180 \mathrm{MPa}$ & $\sim 55,000$ & $\sim 40,000$ & $\sim 50,000$ \\
$350 \mathrm{MPa}$ & $\sim 63,000$ & $\sim 50,000$ & $\sim 61,000$ \\
$450 \mathrm{MPa}$ & $\sim 72,000$ & $\sim 60,000$ & $\sim 70,000$ \\
\hline
\end{tabular}

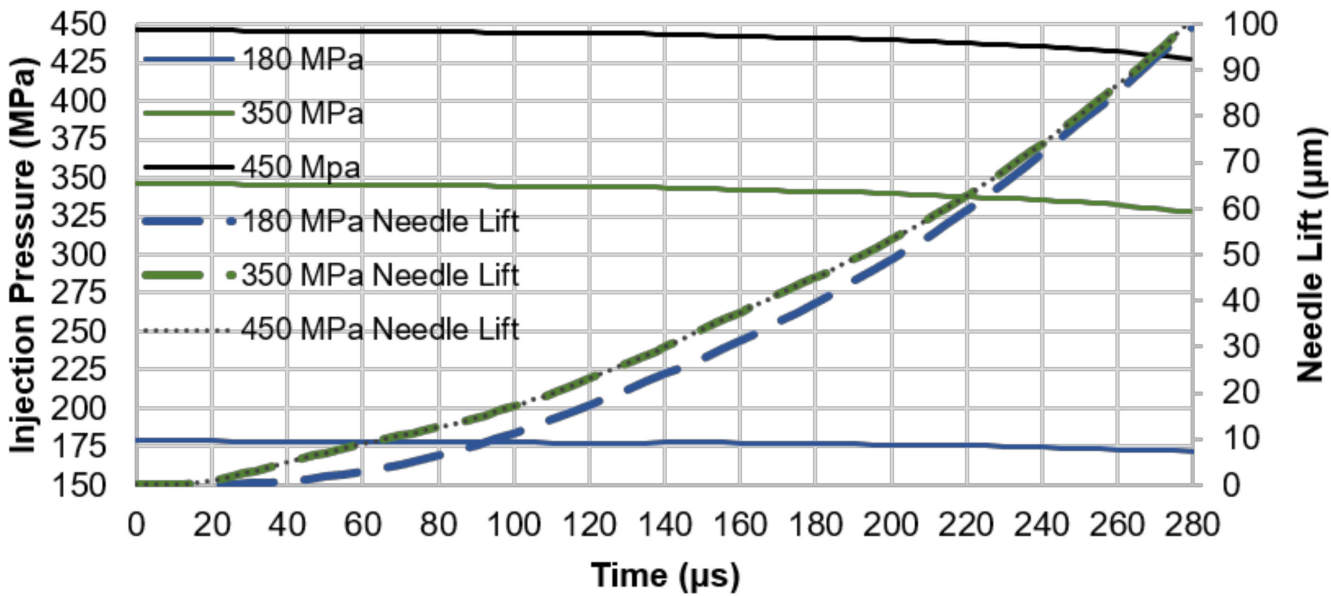

Figure 2. Injection pressure and needle lift profile utilized as the boundary conditions.

Based on the cell sizes indicated in Table 4 and on the flow conditions, it was possible to make an estimation of the Taylor scale of fluid motion for this case (also shown in Table 4). The Taylor length scale gave the characteristic sizes of the inertial scales that transitioned to viscous scales, and was used as a resolution target for the LES. The time step used was $0.5 \mathrm{~ns}$, which corresponded to an acoustic Courant number (CFL) of $\sim 0.7$ for the $180 \mathrm{MPa}$ case and (CFL) $\sim 0.5$ for the $350 \mathrm{MPa}$ and $450 \mathrm{MPa}$ test cases. This was also smaller than the Kolmogorov time scale throughout the computational domain.

Table 4. Taylor microscales of the fluid motion for the injector's different part.

\begin{tabular}{cccccc}
\hline Region & $\begin{array}{c}\text { Taylor } \\
\text { Length Scale } \\
\mathbf{1 8 0 ~} \mathbf{M P a}\end{array}$ & $\begin{array}{c}\text { Taylor } \\
\text { Length Scale } \\
\mathbf{3 5 0} \mathbf{~ M P a}\end{array}$ & $\begin{array}{c}\text { Taylor } \\
\text { Length Scale } \\
\mathbf{4 5 0} \mathbf{M P a}\end{array}$ & $\begin{array}{c}\text { Smaller Cell } \\
\mathbf{1 8 0 ~} \mathbf{M P a}\end{array}$ & $\begin{array}{c}\text { Smaller Cell } \\
\mathbf{3 5 0 / 4 5 0} \mathbf{M P a}\end{array}$ \\
\hline Needle Seat & $3 \mu \mathrm{m}$ & $1.6 \mu \mathrm{m}$ & $1.4 \mu \mathrm{m}$ & $1 \mu \mathrm{m}$ & $1 \mu \mathrm{m}$ \\
Sac Volume & $9 \mu \mathrm{m}$ & $6.2 \mu \mathrm{m}$ & $5.5 \mu \mathrm{m}$ & $7 \mu \mathrm{m}$ & $5 \mu \mathrm{m}$ \\
Orifice & $4.7 \mu \mathrm{m}$ & $3.8 \mu \mathrm{m}$ & $3.4 \mu \mathrm{m}$ & $2 \mu \mathrm{m}$ & $1.8 \mu \mathrm{m}$ \\
\hline
\end{tabular}




\section{Results}

\subsection{Cavitation Development during the Early Opening Phase}

During the early opening stage, which lasted between $2-80 \mu \mathrm{m}$, cavitation appeared at the needle seat passage and inside the sac volume. Gradually, cavitation disappeared from the needle valve seat and was established only in the orifice volume; the transition of cavitation formation from the lower to upper side of the orifice entrance was predicted. As shown in Figure 3, the mass flow rate values were lower than $0.17 \mathrm{~kg} / \mathrm{s}$ for the $180 \mathrm{MPa}$ case and lower than $0.25 \mathrm{~kg} / \mathrm{s}$ and $0.3 \mathrm{~kg} / \mathrm{s}$ for the other two cases, respectively. Using the theoretical mass flow rate from Table 5 , the numerical model predicted discharge coefficients (Cd) at a $80 \mu \mathrm{m}$ needle lift of $\sim 0.89, \sim 0.78$, and $\sim 0.72$, for the three injection pressures simulated, respectively.

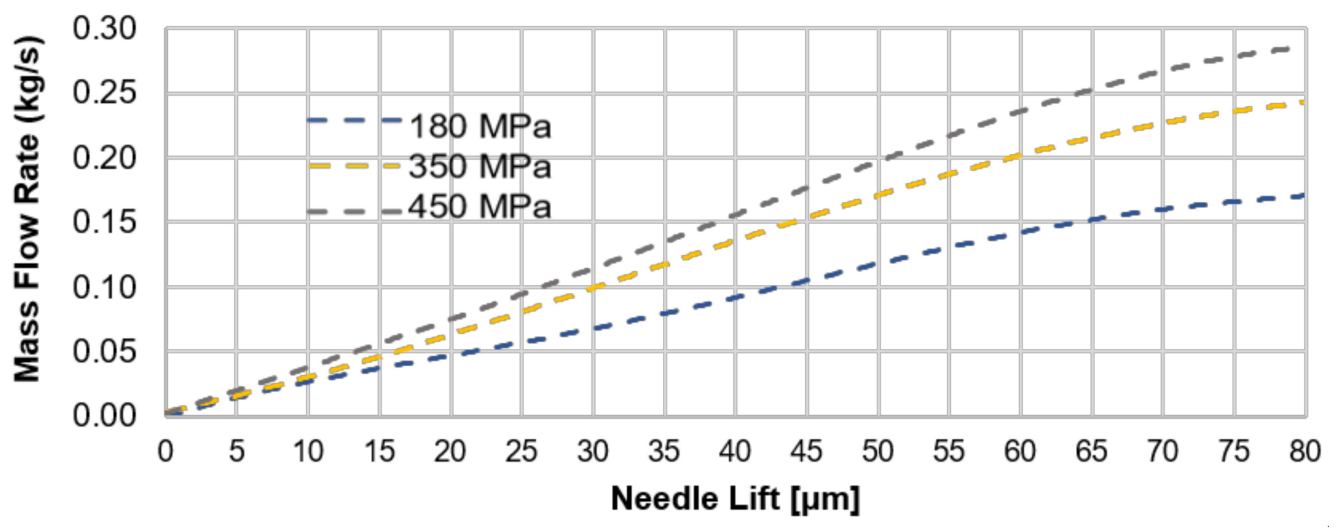

Figure 3. Mass flow rate at the orifice exit for all of the simulated cases.

Table 5. Theoretical mass flow rate at an $80 \mu \mathrm{m}$ needle valve.

\begin{tabular}{ccccc}
\hline Property & Unit & $\mathbf{1 8 0 ~} \mathbf{M P a}$ & $\mathbf{3 5 0} \mathbf{~ M P a}$ & $\mathbf{4 5 0} \mathbf{~ M P a}$ \\
\hline Mean pressure in sac volume & {$[\mathrm{MPa}]$} & 150 & 270 & 350 \\
Mean density in sac volume & {$\left[\mathrm{kg} / \mathrm{m}^{3}\right]$} & 853 & 872 & 890 \\
Theoretical mass flow rate & {$[\mathrm{kg} / \mathrm{s}]$} & 0.19 & 0.31 & 0.39 \\
\hline
\end{tabular}

Figure 4 shows the maximum velocity developed in the needle seat passage during this time period. For instance, at $20 \mu \mathrm{m}$, the velocity for the $180 \mathrm{MPa}$ case was $\sim 750 \mathrm{~m} / \mathrm{s}$ and increased up to $850 \mathrm{~m} / \mathrm{s}$ and $1100 \mathrm{~m} / \mathrm{s}$ (Mach number $=0.96$ for liquid phase) for the $350 \mathrm{MPa}$ and $450 \mathrm{MPa}$ cases, respectively. The normalized volume of the cavitation vapor during this injection period is shown in Figure 5. Th vapor volume was normalized by the sum of the injector's needle seat passage, sac, and orifice volumes. Cavitation dominated in the needle seat area and the sac volume. The increased pressures found overall also affected the amount of vapor volume. Differences were realized during the following two stages: "stage 1", lasting between $2 \mu \mathrm{m}$ and $20 \mu \mathrm{m}$, followed by "stage 2", lasting between $20 \mu \mathrm{m}$ to $60 \mu \mathrm{m}$. The instantaneous total amount of vapor in the domain showed noticeable differences, especially for a lower than $20 \mu \mathrm{m}$ needle lift, up to $60 \%, 45 \%$, and $43 \%$ for the $450 \mathrm{MPa}, 350 \mathrm{MPa}$, and $180 \mathrm{MPa}$ cases, respectively. During stage 1, the amount of vapor was not noticeably higher for the $450 \mathrm{MPa}$ case; however, this trend was seen only during that short period, where the needle valve lift was below $20 \mu \mathrm{m}$. During the early stage of the needle valve opening, similar flow patterns for all injection pressure cases were predicted. Figure 6 shows local pressures developing into the sac volume; clearly higher pressures develop with increasing injection pressure.

Figure 7 shows the vapor volume inside the injector at different injection pressures, with the cavitation cloud colored by both the vapor volume fraction and the local temperature. In Figure 7a, at $20 \mu \mathrm{m}$, needle lift sheet cavitation formed in the needle seat passage. Part of the sac volume was occupied by a vortex cavitation pattern, while cavitation was 
also formed inside the injection hole. Vapor appeared on the needle surface wall, and the vapor temperature exceeded the fuel boiling temperature $(520 \mathrm{~K})$ for both the 350 and $450 \mathrm{MPa}$ cases. Fully developed cavitation and a cavitating vortex were formed for the higher injection pressures, while cavitation formed at the periphery of the entrance nozzle orifice for the $180 \mathrm{MPa}$ case.

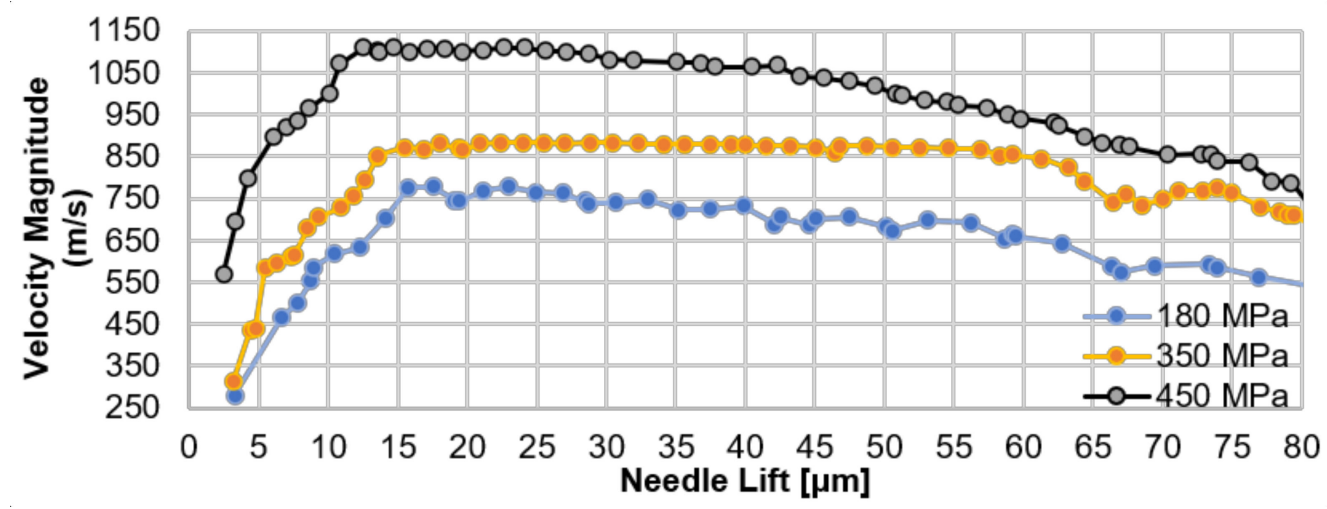

Figure 4. Temporal evolution of the maximum velocity magnitude at the narrowest point of the needle seat passage indicating the lift increase from $2 \mu \mathrm{m}$ to $80 \mu \mathrm{m}$ over the simulated time.

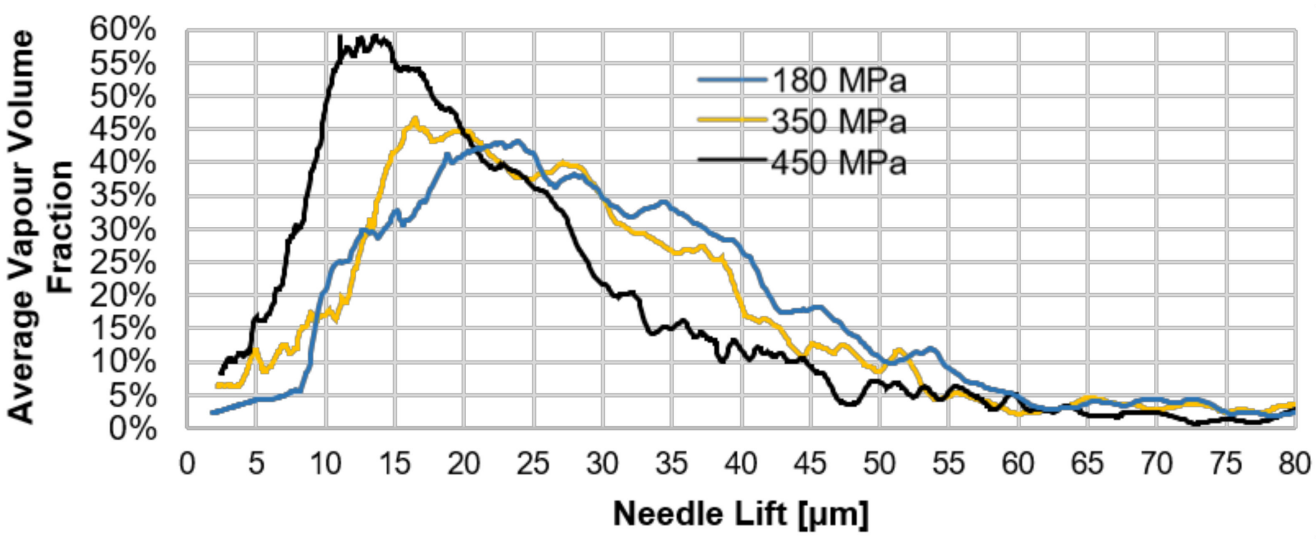

Figure 5. Vapor volume fraction in the injector volume during the early opening phase of the needle valve. The vapor volume is normalized by the sum of the needle seat passage volume below the narrowest point, the injector's sac, and the orifice volumes. It is noted that at zero needle lift, the sac volume is 3.1 times larger than the volume of the orifice.

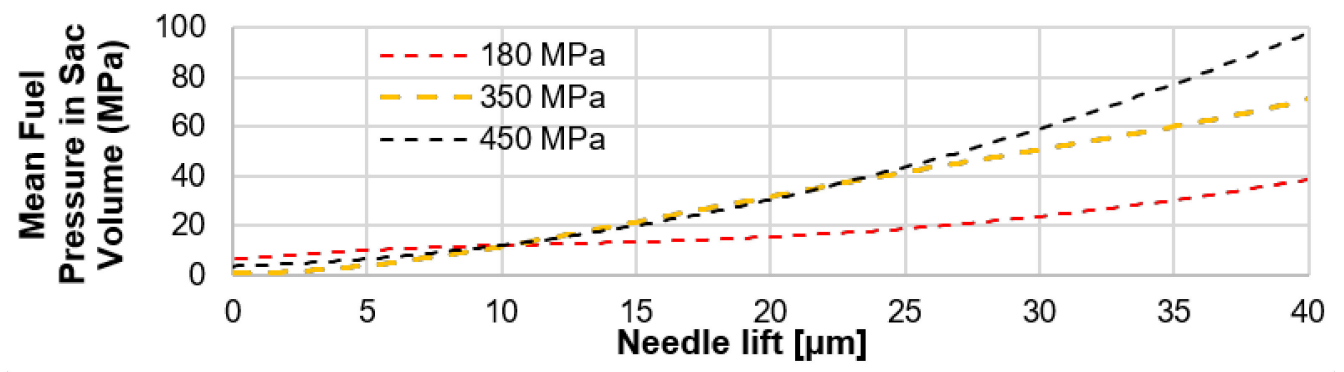

Figure 6. Temporal evolution of fuel pressure in the injector's sac volume for lift increases from $2 \mu \mathrm{m}$ to $40 \mu \mathrm{m}$ during the plotted time. 


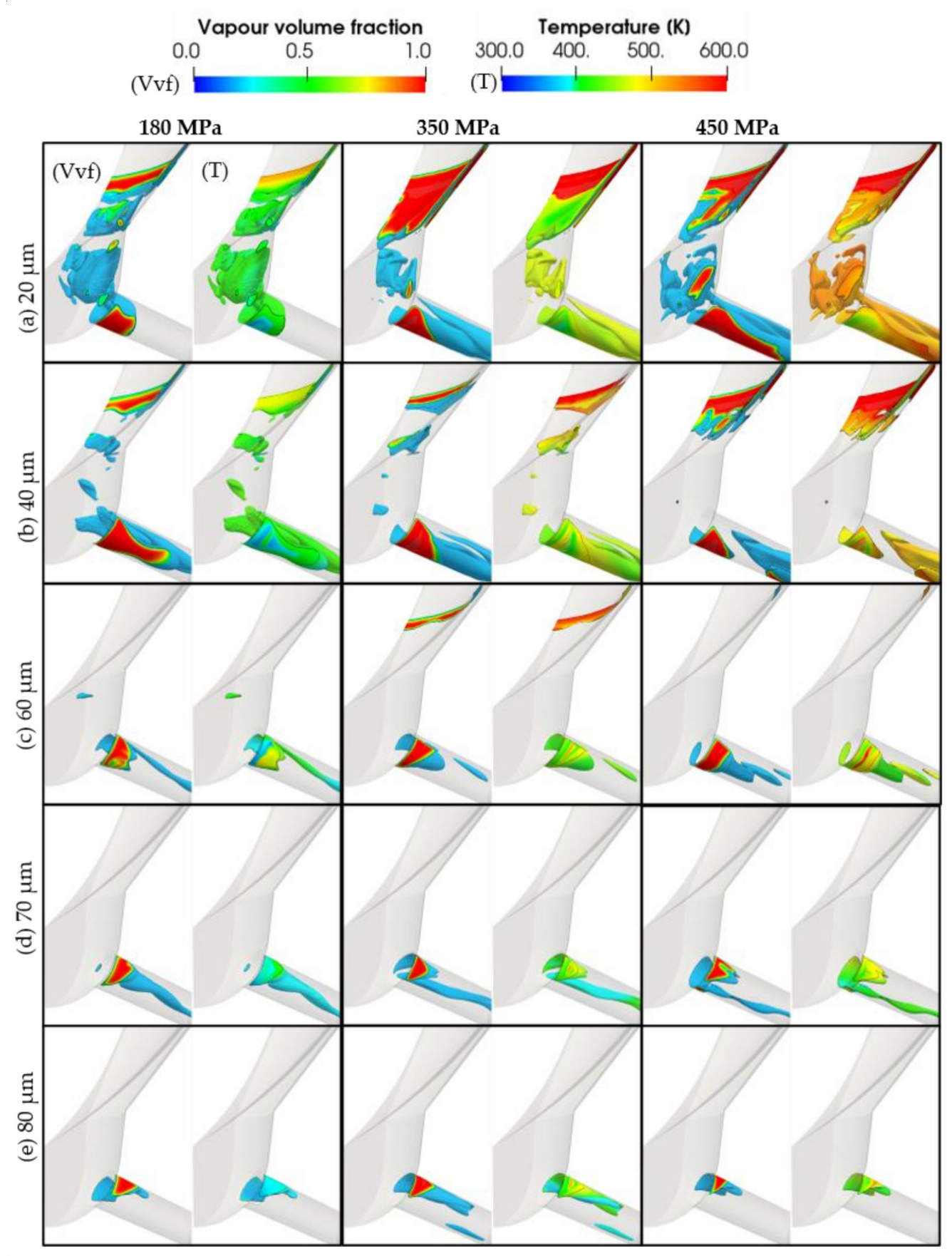

Figure 7. Snapshots of cavitation formation colored by both the vapor volume fraction and temperature during the opening of the needle valve. The time instants correspond to needle lifts of: (a) $20 \mu \mathrm{m}$, (b) $40 \mu \mathrm{m}$, (c) $60 \mu \mathrm{m}$, (d) $70 \mu \mathrm{m}$, and (e) $80 \mu \mathrm{m}$.

As seen in Figure $7 \mathrm{~b}$, cavitation in the needle seat passage was reduced significantly for all of the cases when compared with Figure 7a. The vapor volume inside the injector's sac volume almost disappeared for the $450 \mathrm{MPa}$ case compared with the previous needle lift for the same injection pressure. However, at $180 \mathrm{MPa}$, the cavitation was more extended compared with the 450 and $350 \mathrm{MPa}$ cases for the same needle lift. In Figure 7c, cavitation remained on the needle upper surface for the 350 and $450 \mathrm{MPa}$ cases because of the higher jet velocity developing in needle seat passage. There was no vapor formation inside the injector's sac volume for the $350 \mathrm{MPa}$ and $450 \mathrm{MPa}$ cases. However, for the $180 \mathrm{MPa}$ case, vortex cavitation appeared, despite the fact that the vortex coherent structure was smaller than in the other two cases. 
In Figure $7 \mathrm{~d}$, cavitation formed close to the upper orifice surface and the cavitation structures spanned the whole orifice length, forming a thinner string cavitation for the $450 \mathrm{MPa}$ case. As seen in Figure 7e, fully developed cavitation formation was observed at the upper orifice surface and an unstable streamwise aligned vortex cavitation structure appeared in the orifice volume. As seen in Figure 7e, at the $80 \mu \mathrm{m}$ lift, the amount of vapor was almost identical between the $180 \mathrm{MPa}$ and $450 \mathrm{MPa}$ cases because of the pressure distribution inside the orifice; as the injection pressure increased, so too did the pressure inside the orifice volume, confirming that the location of the cavitation formation was restricted to the smaller volume attached to the upper part of orifice. Thus, cavitation growth was restricted, as shown by the patterns depicted in Figure 5, at an $80 \mu \mathrm{m}$ lift. Moreover, the increase in saturation pressure as the injection pressures increased was another significant factor [40].

\subsection{Analysis of Fuel Heating and Cooling}

CFD predictions were obtained by assuming an initial fuel temperature of $350 \mathrm{~K}$.

As shown in Figure 8, the comparison between the temporal evolution of the fuel temperature at the exit of the injector's orifice and at the sac volume entrance revealed that the temperature profiles showed different trends, even for the same injection pressure. An increase in temperature was observed, particularly during the early needle opening, at $0-15 \mu \mathrm{m}$, where an increase up to $\sim 80, \sim 110$ and $\sim 180$ degrees was estimated for the 180,350 , and $450 \mathrm{MPa}$ injection pressures, respectively. This pattern after the needle seat passage may have been caused by the presence of the cooling effect for all of the cases after the $60 \mu \mathrm{m}$ lift.

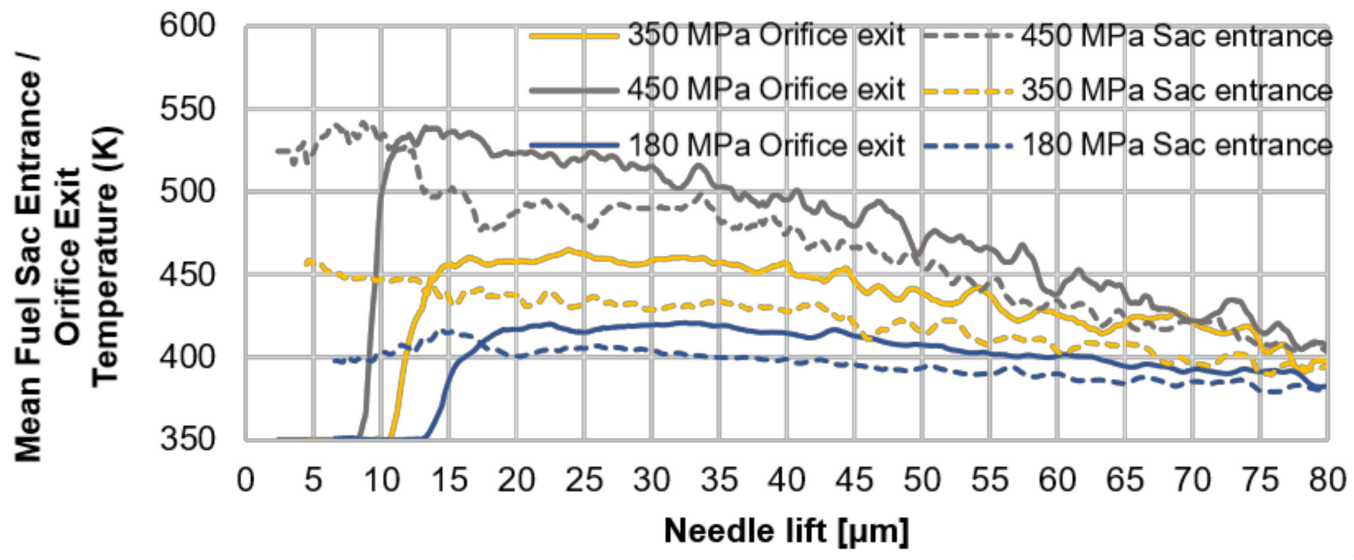

Figure 8. Temporal evolution of the fuel temperature at the exit of the injector's orifice (solid lines) and at the sac entrance (dashed lines) for lift increases from $0 \mu \mathrm{m}$ to $80 \mu \mathrm{m}$ for the plotted time.

At a higher needle lift of $40 \mu \mathrm{m}$, as shown in Figure 9b, both viscous heating and cooling of the fuel took place for the 180 and $350 \mathrm{MPa}$ cases, but for the $450 \mathrm{MPa}$ case, there was an absence of fuel cooling until this needle lifted. Predictions indicated that the liquid fuel temperatures in the needle seat passage were 10-15 K lower than that of the inlet fuel temperature. As seen in Figure 9c,d, the cooler fuel jets were more extended and $25-30 \mathrm{~K}$ lower than that of the feed fuel temperature. The downwards displacement of the needle valve pushed the fuel from the sac volume towards the injection hole. 


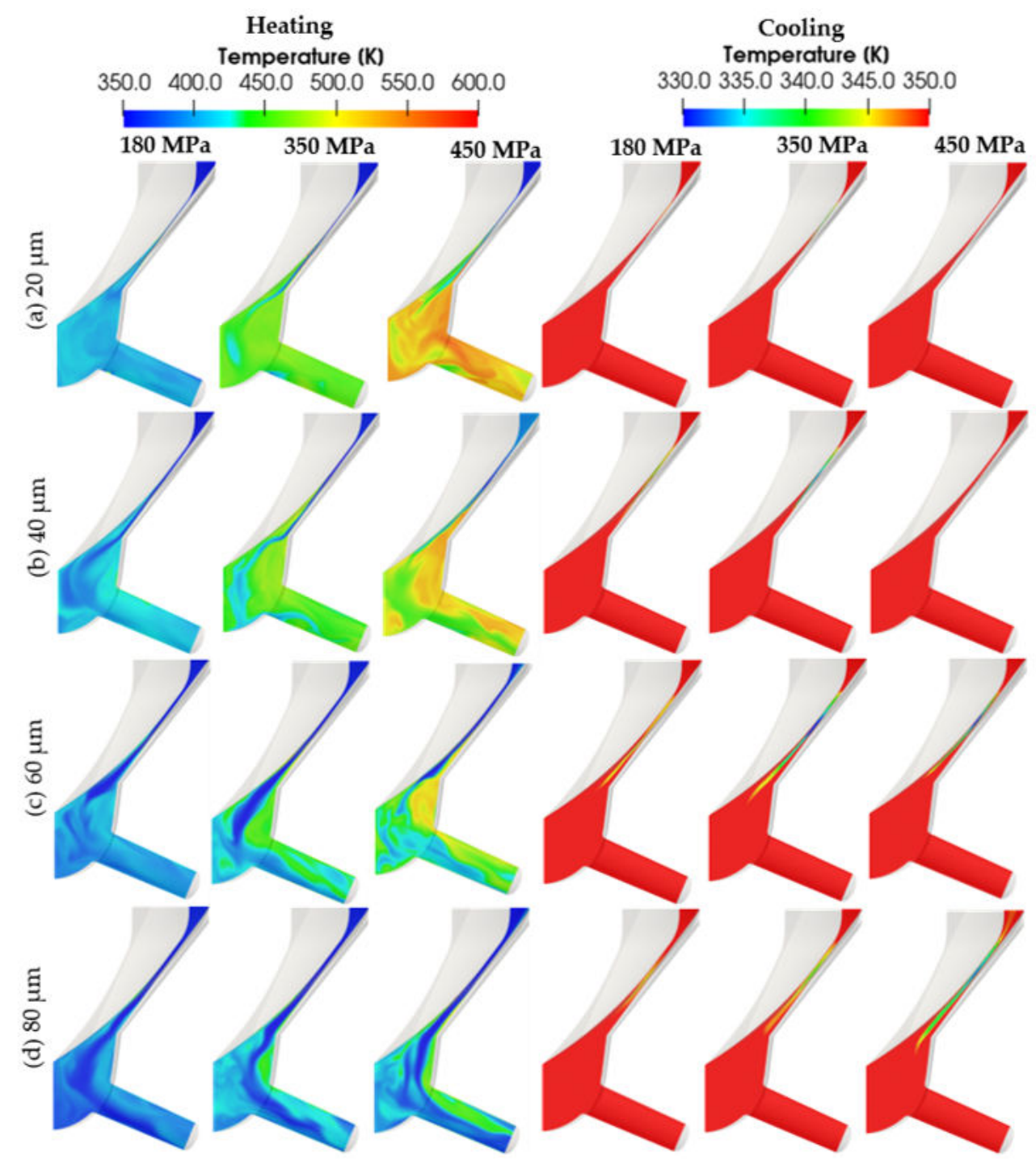

Figure 9. Snapshots of the instantaneous temperature field on the mid-plane of the injector. The time instants correspond to needle lifts of: (a) $20 \mu \mathrm{m},(\mathbf{b}) 40 \mu \mathrm{m}$, (c) $60 \mu \mathrm{m}$, and (d) $80 \mu \mathrm{m}$.

\subsection{Analysis of the Flow Field and Vortex Structures}

In Figure 10, the velocity magnitude fields revealed a similar behavior during the opening period of the needle valve under different injection pressures; however, some significant differences were realized near the vertical sac wall. The unsteady flow of the fuel jet and the strong turbulence inside the sac volume made the jet detach from the needle seat surface for the $450 \mathrm{MPa}$ case, while for the other two cases, the jet remains attached during the early opening phase, as depicted in Figure 10b,c. In addition, at a $80 \mu \mathrm{m}$ needle lift, as shown in Figure 10d, the flow was attached to the vertical wall of the sac volume only for the $450 \mathrm{MPa}$ case.

In Figure 11, focus was placed on the visualization of the vortex formation and its evolution into the sac volume. The depicted time instances highlight the interaction of this vortex structure with the flow inside the sac volume up to the needle wall surface, as illustrated in Figure 11a,b. One part of the fuel moved backward into the passage close to the curved needle surface. At the same time, part of the fuel moved parallel to the sac vertical wall, and, as a result, the upwards flow collided with the high velocity jet, which came through the needle seat passage at the sac inlet and changed the direction of the jet. 


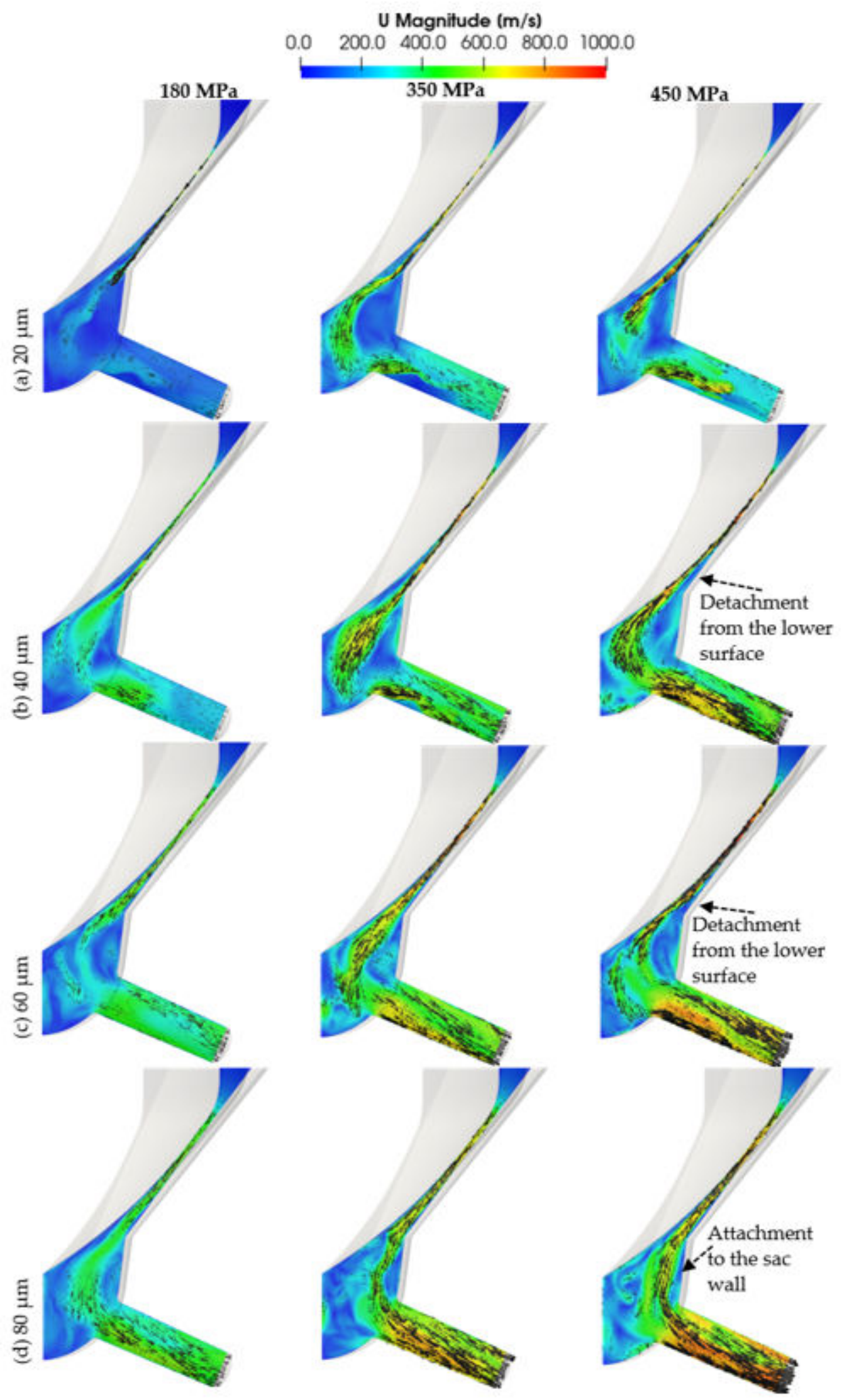

Figure 10. Snapshots of the instantaneous velocity magnitude and flow field vectors plotted at time instances corresponding to: (a) $20 \mu \mathrm{m}$, (b) $40 \mu \mathrm{m}$, (c) $60 \mu \mathrm{m}$, and (d) $80 \mu \mathrm{m}$.

In Figure 11, a large unstable vortex structure occupied the region close to the sac wall and before the orifice entrance, while a smaller vortex structure developed at the lower surface of the center region of the sac volume. One significant observation is that the vortices' locations were the same for all of the cases. However, their growth was different; 
the higher the injection pressure, the stronger the upper vortex, with velocity magnitudes (close to sac vertical wall) reaching $300 \mathrm{~m} / \mathrm{s}, 380 \mathrm{~m} / \mathrm{s}$, and $500 \mathrm{~m} / \mathrm{s}$ for the three injection pressures, respectively, as shown in Figure 11a,b.

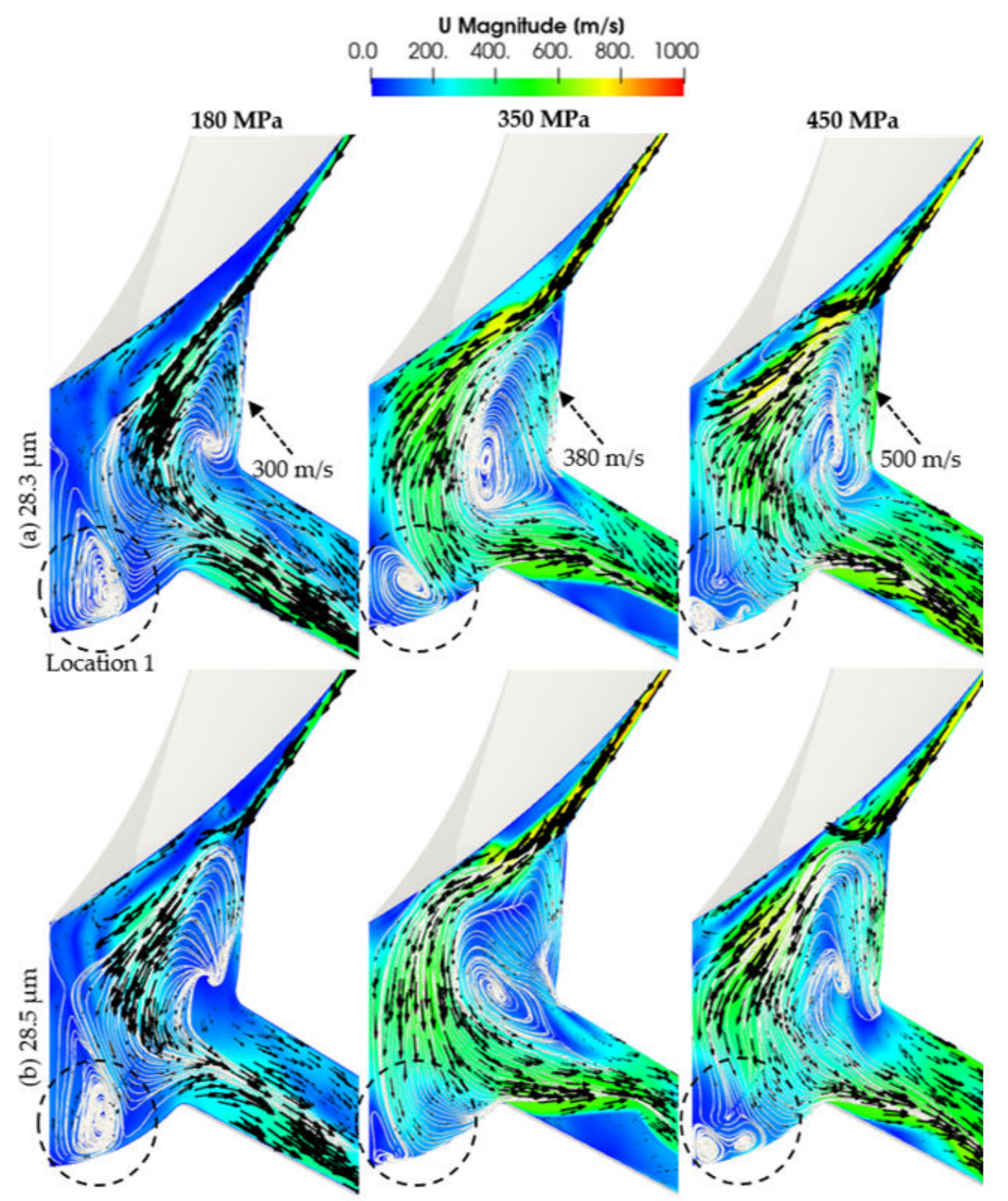

Figure 11. Snapshots of the predicted flow field and flow streamlines at selected time shots $(\mathbf{a}, \mathbf{b})$.

\subsection{Analysis of Analysis of Erosion Pattern and Erosion Assessment}

The mitigation of possible erosion areas during the design process of diesel fuel injectors is a significant factor for efficient operation and durability. In Figure 12, potential erosion areas due to local the maximum accumulated pressure peaks on the injector surfaces are shown. From the experiments, a clear pattern was identified with erosion formation on the needle surface in the form of a deeply engraved ring shape, as analyzed in [46]. The pressure peaks were predicted in the needle seat passage region between a $10 \mu \mathrm{m}$ and $45 \mu \mathrm{m}$ needle lift. 
Considering the other surfaces of the nozzle, the sac was less affected by erosion very close to the orifice inlet. In the nozzle holes, the injector was generally less prone to erosion damage, where minor pits on the top side of the injection hole entrance were observed. Moreover, some signs of erosion damage inside the sac volume existed. The value of the pressure peaks and the location of the erosion ring on the upper orifice surface were strongly corelated with (1) the vortex pattern in the sac volume and (2) with the velocity of the fuel jet, from the needle seat passage to the sac volume. As reported in [46] these locations of cavitation erosion for the $180 \mathrm{MPa}$ case have been confirmed experimentally. However, under higher injection pressures, there are no experimental data.

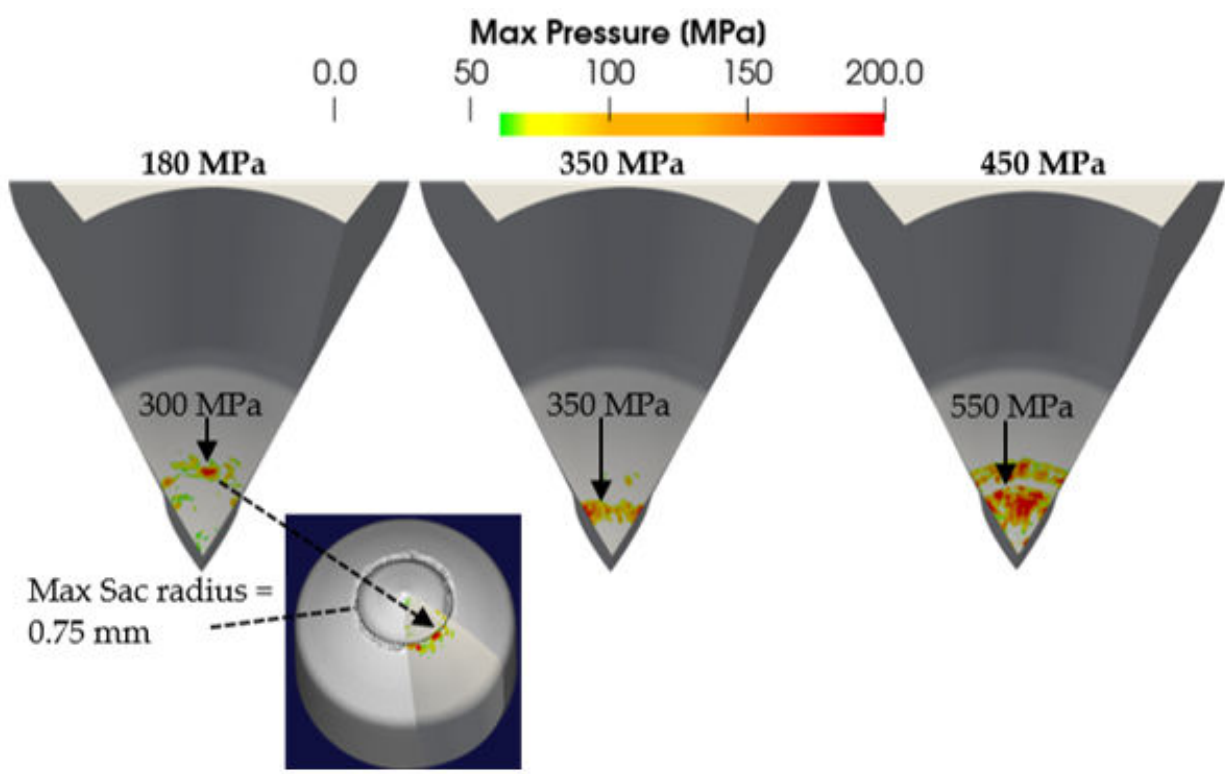

Figure 12. Spatial distribution of the accumulated pressure peaks on the surface of the needle valve. Strongest collapse events are located on the needle surface, reaching up to $550 \mathrm{MPa}$ for the $450 \mathrm{MPa}$ injection pressure case.

\section{Discussion}

Two mechanisms affect the temperature distribution within the fuel injector. The first is as a result of the strong viscous heating produced by the wall friction, leading to a significant increase in the fuel temperature at the upper orifice surface, where local temperatures could exceed the fuel's boiling temperature and superheated vapor forms. At the same time, liquid expansion due to depressurization results in liquid cooling relative to the fuel's feed temperature. This is observed at the central part of the injection orifice. The results indicate that when increasing the injection pressure, an unprecedented decrease of the cavitation volume inside the fuel injector occurs. This has been attributed to the shift in pressure drop from the feed to the back pressure within the injection orifice as the fuel discharges. Moreover, a significant increase in temperature in the needle seat passage takes place during the early stages of the needle valve opening, because of the very high velocity magnitude, in the of order $1000 \mathrm{~m} / \mathrm{s}$. Additionally, stronger fuel cooling at the bulk of the flow is predicted. It is evident that the needle motion affects the thermal boundary layer, as well as the inception and growth of the formed cavity sheet, especially at low needle lifts. Finally, the size and growth of strong vortices inside the sac volume influence the locations expected to be more vulnerable to cavitation erosion. Overall, the comparison between these injection pressures shows that there are minor differences in the predicted mean fuel temperature and vapor volume after $60 \mu \mathrm{m}$, but significant differences in the temperature distribution and vapor volume inside the sac, needle, and orifice injector regions from 0 to $60 \mu \mathrm{m}$. In the present study, the effect of non-condensable gas has not been considered. As an extension of this work, it will be helpful to consider the link between cavitation 
and vortex cavitation patterns and the near nozzle primary breakup, spray angle, and fuel atomization.

\section{Conclusions}

A compressible explicit density-based solver of the Navier-Stokes and energy conservation equations has been employed for simulating the development of cavitation in a five-hole common rail diesel injector. For the multiphase solver developed in OpenFOAM ${ }^{\circledR}$, the HEM approach, extended by the arbitrary Lagrangian-Eulerian (ALE) formulation, is used for modelling the injector's needle valve movement. The thermodynamic closure model is based on the tabulated data for a four-component diesel fuel surrogate, derived from the perturbed chain statistical associating fluid theory (PC-SAFT) EoS, which enabled the strong variation of fuel properties with injection pressure to be quantified. The employed numerical model has, for the first time, considered the variation of the fuel's physical properties up to $450 \mathrm{MPa}$ and their effect on the flow inside the diesel injector during the opening phase of the needle valve. Moreover, LES has resolved the in-nozzle flow for the real-world fuels considered here, utilizing the upcoming injection conditions for heavy duty engines. It is evident that prediction cavitation erosion-sensitive areas are affected by including the unsteady needle valve motion.

Author Contributions: K.K., conceptualization, methodology, software, validation, formal analysis, investigation, data curation, visualization, writing-original draft, review and editing. P.K., supervision, project administration, funding acquisition, writing-review and editing. R.M.M., project administration, writing-review and editing. M.G., conceptualization, supervision, project administration, funding acquisition, writing-review and editing. All authors have read and agreed to the published version of the manuscript.

Funding: The author(s) disclosed receipts of the following financial support for the research, authorship, and/or publication of the article: This project has received funding from the European Union Horizon 2020 Research and Innovation Program (Grant agreement No. 675528).

Institutional Review Board Statement: Not applicable.

Informed Consent Statement: Not applicable.

Data Availability Statement: Not applicable.

Acknowledgments: CAT: CATERPILLAR, their respective logos, "Caterpillar Yellow", the "Power Edge" trade dress, as well as corporate and product identity used herein, are trademarks of Caterpillar and may not be used without permission. 2021 Caterpillar, All Rights Reserved.

Conflicts of Interest: The authors declare no conflict of interest.

\section{References}

1. United Nations Environment Programme. Emissions Gap Report 2020. Available online: http://www.unenvironment.org/ emissions-gap-report-2020 (accessed on 13 January 2021).

2. Exonmobil. 2019 Outlook for Energy. Available online: https://corporate.exxonmobil.com/-/media/Global/Files/outlook-forenergy /2019-Outlook-for-Energy_v4.pdf (accessed on 13 January 2021).

3. Lemaire, R.; Faccinetto, A.; Therssen, E.; Ziskind, M.; Focsa, C.; Desgroux, P. Experimental comparison of soot formation in turbulent flames of Diesel and surrogate Diesel fuels. Proc. Combust. Inst. 2009, 32, 737-744. [CrossRef]

4. Kook, S.; Pickett, L.M. Liquid length and vapor penetration of conventional, Fischer-Tropsch, coal-derived, and surrogate fuel sprays at high-temperature and high-pressure ambient conditions. Fuel 2012, 93, 539-548. [CrossRef]

5. Hawi, M.; Kosaka, H.; Sato, S.; Nagasawa, T.; Elwardany, A.; Ahmed, M. Effect of injection pressure and ambient density on spray characteristics of diesel and biodiesel surrogate fuels. Fuel 2019, 254, 115674. [CrossRef]

6. Payri, R.; Viera, J.P.; Pei, Y.; Som, S. Experimental and numerical study of lift-off length and ignition delay of a two-component diesel surrogate. Fuel 2015, 158, 957-967. [CrossRef]

7. Donkerbroek, A.; Boot, M.; Luijten, C.; Dam, N.; Meulen, J. Flame lift-off length and soot production of oxygenated fuels in relation with ignition delay in a DI heavy-duty diesel engine. Combust. Flame 2011, 158, 525-538. [CrossRef]

8. Arcoumanis, C.; Gavaises, M.; Argueyrolles, B.; Galzin, F. Modeling of Pressure-Swirl Atomizers for GDI Engines. SAE Tech. Paper Ser. 1999, 108. [CrossRef] 
9. Han, Z.; Uludogan, A.; Hampson, G.J.; Reitz, R.D. Mechanism of Soot and NOx Emission Reduction Using Multiple-Injection in a Diesel Engine. SAE Trans. 1996, 105, 837-852.

10. Ribeiro, N.M.; Pinto, A.C.; Quintella, C.M.; Da Rocha, G.O.; Teixeira, L.S.G.; Guarieiro, L.L.N.; Rangel, M.D.C.; Veloso, M.C.C.; Rezende, M.J.C.; Da Cruz, R.S.; et al. The Role of Additives for Diesel and Diesel Blended (Ethanol or Biodiesel) Fuels: A Review. Energy Fuels 2007, 21, 2433-2445. [CrossRef]

11. Payri, F.; Pastor, J.V.; Nerva, J.-G.; Garcia-Oliver, J.M. Lift-Off Length and KL Extinction Measurements of Biodiesel and Fischer-Tropsch Fuels under Quasi-Steady Diesel Engine Conditions. SAE Int. J. Engines 2011, 4, 2278-2297. [CrossRef]

12. Pickett, L.M.; Siebers, D.L. Soot in diesel fuel jets: Effects of ambient temperature, ambient density, and injection pressure. Combust. Flame 2004, 138, 114-135. [CrossRef]

13. Nishida, K.; Zhu, J.; Leng, X.; He, Z. Effects of micro-hole nozzle and ultra-high injection pressure on air entrainment, liquid penetration, flame lift-off and soot formation of diesel spray flame. Int. J. Engine Res. 2017, 18, 51-65. [CrossRef]

14. Riva, G.E.; Reggiori, A.; Daminelli, G. Diesel Spray Combustion Rate Enhancement by Increasing Injection Pressure. SAE Tech Paper Ser. 1993. [CrossRef]

15. Vera-Tudela, W.; Haefeli, R.; Barro, C.; Schneider, B.; Boulouchos, K. An experimental study of a very high-pressure diesel injector (up to 5000 bar) by means of optical diagnostics. Fuel 2020, 275, 117933. [CrossRef]

16. Chahine, G.L.; Kapahi, A.; Choi, J.-K.; Hsiao, C.-T. Modeling of surface cleaning by cavitation bubble dynamics and collapse. Ultrason. Sonochem. 2016, 29, 528-549. [CrossRef]

17. Koukouvinis, P.; Strotos, G.; Zeng, Q.; Gonzalez-Avila, S.R.; Theodorakakos, A.; Gavaises, M.; Ohl, C.-D. Parametric Investigations of the Induced Shear Stress by a Laser-Generated Bubble. Langmuir 2018, 34, 6428-6442. [CrossRef]

18. Reitz, R.D. Mechanism of atomization of a liquid jet. Phys. Fluids 1982, 25, 1730. [CrossRef]

19. Lin, S.P.; Reitz, R.D. Drop and spray formation from a liquid jet. Annu. Rev. Fluid Mech. 1998, 30, 85-105. [CrossRef]

20. Tamaki, N.; Shimizu, M. Enhancement of Atomization of High Viscous Liquid Jet by Pressure Atomized Type Nozzle. In Proceedings of the Chugoku-Shikoku Branch, Japan Society of Mechanical Engineers, Tokyo, Japan, 9-11 September 2002; pp. 167-168.

21. Sou, A.; Hosokawa, S.; Tomiyama, A. Effects of cavitation in a nozzle on liquid jet atomization. Int. J. Heat Mass Transf. 2007, 50, 3575-3582. [CrossRef]

22. Dular, M.; Bachert, B.; Stoffel, B.; Širok, B. Relationship between cavitation structures and cavitation damage. Wear 2004, 257, 1176-1184. [CrossRef]

23. Zhang, L.; He, Z.; Guan, W.; Wang, Q.; Som, S. Simulations on the cavitating flow and corresponding risk of erosion in diesel injector nozzles with double array holes. Int. J. Heat Mass Transf. 2018, 124, 900-911. [CrossRef]

24. Gavaises, M. Flow in valve covered orifice nozzles with cylindrical and tapered holes and link to cavitation erosion and engine exhaust emissions. Int. J. Engine Res. 2008, 9, 435-447. [CrossRef]

25. Payri, R.; Salvador, F.; Gimeno, J.; Zapata, L. Diesel nozzle geometry influence on spray liquid-phase fuel penetration in evaporative conditions. Fuel 2008, 87, 1165-1176. [CrossRef]

26. Strotos, G.; Koukouvinis, P.; Theodorakakos, A.; Gavaises, M.; Bergeles, G. Transient heating effects in high pressure Diesel injector nozzles. Int. J. Heat Fluid Flow 2015, 51, 257-267. [CrossRef]

27. Theodorakakos, A.; Strotos, G.; Mitroglou, N.; Atkin, C.; Gavaises, M. Friction-induced heating in nozzle hole micro-channels under extreme fuel pressurisation. Fuel 2014, 123, 143-150. [CrossRef]

28. Theodorakakos, A.; Mitroglou, N.; Gavaises, M. Simulation of Heating Effects Caused by Extreme Fuel Pressurisation in Cavitating Flows through Diesel Fuel Injectors. In Proceedings of the 8th International Symposium on Cavitation, Singapore, 13-16 August 2012; pp. 520-526.

29. Salemi, R.; Koukouvinis, P.; Strotos, G.; McDavid, R.; Wang, L.; Li, J.; Marengo, M.; Gavaises, M. Evaluation of friction heating in cavitating high pressure Diesel injector nozzles. In Proceedings of the 9th International Symposium on Cavitation, Lausanne, Switzerland, 6-10 December 2015.

30. Strotos, G.; Koukou, P.; Theodorakakos, A.; Gavaises, M. Quantification of Friction-induced Heating in tapered Diesel orifices. In Proceedings of the SIA International Conference on Diesel Powertrains, Rouen, France, 21-22 May 2014.

31. Kolev, N.I. Thermodynamic and transport properties of diesel fuel. In Multiphase Flow Dynamics 3; Springer: Berlin/Heidelberg, Germany, 2007; pp. 269-302.

32. Rokni, H.B.; Moore, J.D.; Gupta, A.; McHugh, M.A.; Gavaises, M. Entropy scaling based viscosity predictions for hydrocarbon mixtures and diesel fuels up to extreme conditions. Fuel 2019, 241, 1203-1213. [CrossRef]

33. Rokni, H.B.; Gupta, A.; Moore, J.D.; McHugh, M.A.; Bamgbade, B.A.; Gavaises, M.; Mchugh, M.A. Purely predictive method for density, compressibility, and expansivity for hydrocarbon mixtures and diesel and jet fuels up to high temperatures and pressures. Fuel 2019, 236, 1377-1390. [CrossRef]

34. Rokni, H.B.; Moore, J.D.; Gupta, A.; McHugh, M.A.; Mallepally, R.R.; Gavaises, M.; Mchugh, M.A. General method for prediction of thermal conductivity for well-characterized hydrocarbon mixtures and fuels up to extreme conditions using entropy scaling. Fuel 2019, 245, 594-604. [CrossRef]

35. Rodriguez, C.; Rokni, H.B.; Koukouvinis, P.; Gupta, A.; Gavaises, M. Complex multicomponent real-fluid thermodynamic model for high-pressure Diesel fuel injection. Fuel 2019, 257, 115888. [CrossRef] 
36. Koukouvinis, P.; Vidal-Roncero, A.; Rodriguez, C.; Gavaises, M.; Pickett, L. High pressure/high temperature multiphase simulations of dodecane injection to nitrogen: Application on ECN Spray-A. Fuel 2020, 275, 117871. [CrossRef]

37. Rowane, A.J.; Babu, V.M.; Rokni, H.B.; Moore, J.D.; Gavaises, M.; Wensing, M.; Gupta, A.; McHugh, M.A. Effect of Composition, Temperature, and Pressure on the Viscosities and Densities of Three Diesel Fuels. J. Chem. Eng. Data 2019, 64, 5529-5547. [CrossRef]

38. Rowane, A.J.; Mallepally, R.R.; Gupta, A.; Gavaises, M.; McHugh, M.A.; Mchugh, M.A. High-Temperature, High-Pressure Viscosities and Densities of n-Hexadecane, 2,2,4,4,6,8,8-Heptamethylnonane, and Squalane Measured Using a Universal Calibration for a Rolling-Ball Viscometer/Densimeter. Ind. Eng. Chem. Res. 2019, 58, 4303-4316. [CrossRef]

39. Vidal, A.; Rodriguez, C.; Koukouvinis, P.; Gavaises, M.; McHugh, M.A. Modelling of Diesel fuel properties through its surrogates using Perturbed-Chain, Statistical Associating Fluid Theory. Int. J. Engine Res. 2018, 21, 1118-1133. [CrossRef]

40. Vidal, A.; Kolovos, K.; Gold, M.R.; Pearson, R.J.; Koukouvinis, P.; Gavaises, M. Preferential cavitation and friction-induced heating of multi-component Diesel fuel surrogates up to $450 \mathrm{MPa}$. Int. J. Heat Mass Transf. 2021, 166, 120744. [CrossRef]

41. Cristofaro, M.; Edelbauer, W.; Gavaises, M.; Koukouvinis, P. Numerical simulation of compressible cavitating two-phase flows with a pressure-based solver. In Proceedings of the 28th Conference on Liquid Atomization and Spray Systems, Valencia, Spain, 5-8 September 2017.

42. Cristofaro, M.; Edelbauer, W.; Koukouvinis, P.; Gavaises, M. Large Eddy Simulation of the Internal Injector Flow During Pilot Injection. In Proceedings of the 10th International Symposium on Cavitation, Oxford, UK, 14-17 July 2018.

43. Cristofaro, M.; Edelbauer, W.; Koukouvinis, P.; Gavaises, M. Influence of Diesel Fuel Viscosity on Cavitating Throttle Flow Simulations under Erosive Operation Conditions. ACS Omega 2020, 5, 7182-7192. [CrossRef]

44. Cristofaro, M.; Edelbauer, W.; Koukouvinis, P.; Gavaises, M. A numerical study on the effect of cavitation erosion in a diesel injector. Appl. Math. Model. 2020, 78, 200-216. [CrossRef]

45. Koukouvinis, P.; Karathanassis, I.K.; Gavaises, M. Prediction of cavitation and induced erosion inside a high-pressure fuel pump. Int. J. Engine Res. 2018, 19, 360-373. [CrossRef]

46. Koukouvinis, P.; Gavaises, M.; Li, J.; Wang, L. Large Eddy Simulation of Diesel injector including cavitation effects and correlation to erosion damage. Fuel 2016, 175, 26-39. [CrossRef]

47. Devassy, B.M.; Caika, V.; Sampl, P.; Edelbauer, W.; Greif, D. Numerical Investigation of Cavitating Injector Flow Accounting for 3D-Needle Movement and Liquid Compressibility Effects. J. Phys. Conf. Ser. 2015, 656, 012092. [CrossRef]

48. Battistoni, M.; Grimaldi, C.N. Numerical analysis of injector flow and spray characteristics from diesel injectors using fossil and biodiesel fuels. Appl. Energy 2012, 97, 656-666. [CrossRef]

49. He, Z.; Zhong, W.; Wang, Q.; Jiang, Z.; Fu, Y. An investigation of transient nature of the cavitating flow in injector nozzles. Appl. Therm. Eng. 2013, 54, 56-64. [CrossRef]

50. Margot, X.; Hoyas, S.; Fajardo, P.; Patouna, S. A moving mesh generation strategy for solving an injector internal flow problem. Math. Comput. Model. 2010, 52, 1143-1150. [CrossRef]

51. Giussani, F.; Montorfano, A.; Piscaglia, F.; Onorati, A.; Hélie, J.; Aithal, S. Dynamic VOF Modelling of the Internal Flow in GDI Fuel Injectors. Energy Procedia 2016, 101, 574-581. [CrossRef]

52. Wu, Y.; Montorfano, A.; Piscaglia, F.; Onorati, A. A Study of the Organized in-Cylinder Motion by a Dynamic Adaptive Scale-Resolving Turbulence Model. Flow Turbul. Combust. 2017, 100, 797-827. [CrossRef]

53. Örley, F.; Hickel, S.; Schmidt, S.J.; Adams, N. Large-Eddy Simulation of turbulent, cavitating fuel flow inside a 9-hole Diesel injector including needle movement. Int. J. Engine Res. 2016, 18. [CrossRef]

54. Vasilakis, E.S.; Kyriazis, N.; Koukouvinis, P.; Farhat, M.; Gavaises, M. Cavitation induction by projectile impacting on a water jet. Int. J. Multiph. Flow 2019, 114, 128-139. [CrossRef]

55. Zhang, H.; Tan, J.-J.; Cui, D.-M. Study and Application of Overset Unstructured Grid Method. 2010. Available online: https: //www.researchgate.net/publication/292558457_Study_and_application_of_overset_unstructured_grid_method (accessed on 17 May 2021).

56. Khaware, A.; Gupta, V.K.; Srikanth, K.; Azhar, M. Numerical Simulation of Cavitating Flows using Overset Mesh. In Proceedings of the 4th World Congress on Momentum, Heat and Mass Transfer, Rome, Italy, 10-12 April 2019.

57. Koci, C.P.; Fitzgerald, R.P.; Ikonomou, V.; Sun, K. The effects of fuel-air mixing and injector dribble on diesel unburned hydrocarbon emissions. Int. J. Engine Res. 2019, 20, 105-127. [CrossRef]

58. Guventurk, C.; Sahin, M. An Arbitrary Lagrangian Eulerian Formulation with Exact Mass Conservation for the Numerical Simulation of a Rising Bubble. Int. J. Numer. Meth. Eng. 2018, 112. [CrossRef]

59. Kyriazis, N.; Koukouvinis, P.; Gavaises, M. Numerical investigation of bubble dynamics using tabulated data. Int. J. Multiph. Flow 2017, 93, 158-177. [CrossRef]

60. Demirdžić, I.; Perić, M. Space conservation law in finite volume calculations of fluid flow. Int. J. Numer. Methods Fluids 1988, 8 , 1037-1050. [CrossRef]

61. Ducros, F.; Franck, N.; Poinsot, T. Wall-Adapting Local Eddy-Viscosity Models for Simulations in Complex Geometries. Numer. Methods Fluid Dyn. 1998, 6, 293-299.

62. Kolovos, K.; Kyriazis, N.; Koukouvinis, P.; Gavaises, M.; Li, J.Z.; McDavid, R.M. Large-eddy simulation of friction heating and turbulent cavitating flow in a Diesel injector including needle movement. Appl. Energy Combust. Sci. 2020, under review. 
63. Kyriazis, N.; Koukouvinis, P.; Gavaises, M. Modelling cavitation during drop impact on solid surfaces. Adv. Colloid Interface Sci. 2018, 260, 46-64. [CrossRef]

64. Gross, J.; Sadowski, G. Perturbed-Chain SAFT: An Equation of State Based on a Perturbation Theory for Chain Molecules. Ind. Eng. Chem. Res. 2001, 40. [CrossRef]

65. Gavaises, M.; Murali-Girija, M.; Rodriguez, C.; Koukouvinis, P.; Gold, M.; Pearson, R. Numerical simulation of fuel dribbling and nozzle wall wetting. Int. J. Engine Res. 2021. [CrossRef]

66. Gold, M.; Pearson, R.; Turner, J.; Sykes, D.; Stetsyuk, V.; De Sercey, G.; Crua, C.; Murali-Girija, M.; Koukouvinis, F.; Gavaises, M. Simulation and Measurement of Transient Fluid Phenomena within Diesel Injection. SAE Int. J. Adv. Curr. Pract. Mobil. 2019, 1, 291-305. [CrossRef]

67. Santos, E.G.; Shi, J.; Gavaises, M.; Soteriou, C.; Winterbourn, M.; Bauer, W. Investigation of cavitation and air entrainment during pilot injection in real-size multi-hole diesel nozzles. Fuel 2020, 263, 116746. [CrossRef]

68. Santos, E.G.; Shi, J.; Venkatasubramanian, R.; Hoffmann, G.; Gavaises, M.; Bauer, W. Modelling and prediction of cavitation erosion in GDi injectors operated with E100 fuel. Fuel 2021, 289, 119923. [CrossRef]

69. Wang, C.; Adams, M.; Jin, T.; Sun, Y.; Röll, A.; Luo, F.; Gavaises, M. An analytical model of diesel injector's needle valve eccentric motion. Int. J. Engine Res. 2021, 1468087420987367. [CrossRef]

70. Jaberi, F.A.; Colucci, P.J. Large eddy simulation of heat and mass transport in turbulent flows. Part 1: Velocity field. Int. J. Heat Mass Transf. 2003, 46, 1811-1825. [CrossRef] 